\title{
A pooled shRNA screen for regulators of primary mammary stem and progenitor cells identifies roles for Asap1 and Prox1
}

Julie M Sheridan 1,2,5, Matthew E Ritchie ${ }^{4,6}$, Sarah A Best ${ }^{1,5}$, Kun Jiang ${ }^{1}$, Tamara J Beck ${ }^{1}$, François Vaillant ${ }^{1,5}$, Kevin Liu', Ross A Dickins ${ }^{4,5}$, Gordon K Smyth ${ }^{3,6}$, Geoffrey J Lindeman ${ }^{1,7,8}$ and Jane E Visvader ${ }^{1,5^{*}}$

\begin{abstract}
Background: The molecular regulators that orchestrate stem cell renewal, proliferation and differentiation along the mammary epithelial hierarchy remain poorly understood. Here we have performed a large-scale pooled RNAi screen in primary mouse mammary stem cell (MaSC)-enriched basal cells using 1295 shRNAs against genes principally involved in transcriptional regulation.

Methods: MaSC-enriched basal cells transduced with lentivirus pools carrying shRNAs were maintained as non-adherent mammospheres, a system known to support stem and progenitor cells. Integrated shRNAs that altered culture kinetics were identified by next generation sequencing as relative frequency changes over time. RNA-seq-based expression profiling coupled with in vitro progenitor and in vivo transplantation assays was used to confirm a role for candidate genes in mammary stem and/or progenitor cells.

Results: Utilizing a mammosphere-based assay, the screen identified several candidate regulators. Although some genes had been previously implicated in mammary gland development, the vast majority of genes uncovered have no known function within the mammary gland. RNA-seq analysis of freshly purified primary mammary epithelial populations and short-term cultured mammospheres was used to confirm the expression of candidate regulators. Two genes, Asap1 and Prox1, respectively implicated in breast cancer metastasis and progenitor cell function in other systems, were selected for further analysis as their roles in the normal mammary gland were unknown. Both Prox 1 and Asap 1 were shown to act as negative regulators of progenitor activity in vitro, and Asap 1 knock-down led to a marked increase in repopulating activity in vivo, implying a role in stem cell activity.

Conclusions: This study has revealed a number of novel genes that influence the activity or survival of mammary stem and/or progenitor cells. Amongst these, we demonstrate that Prox 1 and Asap 1 behave as negative regulators of mammary stem/progenitor function. Both of these genes have also been implicated in oncogenesis. Our findings provide proof of principle for the use of short-term cultured primary MaSC/basal cells in functional RNAi screens.
\end{abstract}

Keywords: Mammary stem cells, Mammary progenitor cells, Transcription factors, Mammosphere, shRNA screen, Asap1, Prox1

\footnotetext{
* Correspondence: visvader@wehi.edu.au

${ }^{1}$ ACRF Stem Cells and Cancer Division, The Walter and Eliza Hall Institute of

Medical Research, 1G Royal Parade, Parkville, VIC 3052, Australia

${ }^{5}$ Department of Medical Biology, The University of Melbourne, Parkville, VIC

3010, Australia

Full list of author information is available at the end of the article
}

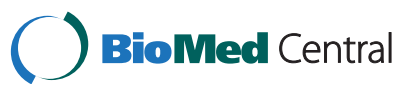

(c) 2015 Sheridan et al.; licensee BioMed Central. This is an Open Access article distributed under the terms of the Creative Commons Attribution License (http://creativecommons.org/licenses/by/4.0), which permits unrestricted use, distribution, and reproduction in any medium, provided the original work is properly credited. The Creative Commons Public Domain Dedication waiver (http://creativecommons.org/publicdomain/zero/1.0/) applies to the data made available in this article, unless otherwise stated. 


\section{Background}

The mammary epithelial tree is a bilayered, branched structure composed of an outer myoepithelial (basal) layer and an inner luminal layer. The full differentiative potential of the mammary gland is manifest in response to pregnancy hormones, when a subset of luminal cells gives rise to alveolar cells that produce milk, which is then extruded through the lumena during lactation. The prospective isolation of mammary stem cells (MaSCs) that are able to give rise to an entire mammary tree upon transplantation at the single cell level $[1,2]$ and the phenotypic identification of several mammary epithelial progenitor cell (MaPC) populations [3-6] have enhanced our current understanding of the differentiation hierarchy. More recently, in vivo genetic tracing experiments have demonstrated the existence of bipotent MaSCs $[7,8]$ and long-lived progenitors $[7,9,10]$ that contribute to morphogenesis in puberty and pregnancy, and ductal maintenance in the adult gland. However, the molecular processes underpinning the functions of stem and progenitor cells remain poorly understood.

Genetic manipulation and pathway interference have been successfully used at the level of single genes to determine the role of regulators of mammary gland morphogenesis (reviewed in [11]). RNAi screening has provided novel molecular insights in different cellular systems but large-scale or genome-wide screens have not yet been performed in the context of primary mammary epithelial cells. Rather, such screening strategies have been restricted to mammary epithelial and breast cancer cell lines, which offer the advantages of being readily available and amenable to genetic manipulation [12-15]. In other organs, primary cells have been used in RNAi screens to study tissue stem and progenitor cell behavior in more complex and physiological contexts [16-19]. To explore novel molecular regulators of MaSCs and MaPCs, we have utilized a targeted shRNA library to interrogate freshly isolated MaSC-enriched cells ex vivo. This study supports the use of large shRNA libraries to identify novel regulators of mammary epithelial function using a non-adherent mammosphere-based assay and has revealed several novel regulators of $\mathrm{MaSC} /$ basal cell function.

\section{Results}

A pooled shRNA screen for the identification of regulators of mammary stem/progenitor cells using primary cells

To identify novel regulators of mammary epithelial stem and progenitor cells, we utilized a GIPZ mouse transcription factor gene shRNA library to perform a screen largely based on proliferation/survival potential using primary mammary epithelial cells. We selected the non-adherent mammosphere assay, which is principally a progenitor assay but is also permissible for the maintenance and differentiation of stem cells [20-22] upon short-term culture. Freshly isolated cells in the $\mathrm{CD} 29^{\mathrm{hi}} \mathrm{CD} 24^{+}$subset (Figure 1A) enriched in transplantable MaSCs, myoepithelial cells and other basal intermediates (MaSC/basal) [1] were first tested in the mammosphere system to study their clonogenic properties ex vivo. Following culture in mammosphere medium, MaSC/basal cells retained the ability to generate colonies in both $2 \mathrm{D}$ assays on irradiated NIH/3T3 feeder layer and 3D Matrigel assays designed to detect MaPC activity (data not shown and Additional file 1: Figure S1A). Importantly, upon transplantation, the ability of mammosphere cells to repopulate a mammary fat pad was maintained during culture at a frequency of 1 in 298 mammosphere cells (Additional file 1: Figure S1B and C).

The suitability of the mammosphere system for a large scale shRNA library screen was next investigated by RNA-seq analysis of freshly sorted $\mathrm{MaSC} /$ basal cells; luminal MaPCs $\left(\mathrm{CD} 29^{\mathrm{lo}} \mathrm{CD} 24^{+} \mathrm{CD} 61^{+}\right.$; LP); a mature luminal cell-enriched $\left(\mathrm{CD} 29^{\mathrm{lo}} \mathrm{CD} 24^{+} \mathrm{CD} 61^{-}\right.$; $\left.\mathrm{ML}\right)$ population; mammosphere-derived cells generated from MaSC/basal cells harvested after 7 days in non-adherent culture; and the Comma $\mathrm{D} \beta$ cell line, which comprises bipotent cells capable of mammary reconstitution [23] (Figure 1B). Comparative analysis revealed that mammosphere cells had an expression profile intermediary to basal and luminal cell populations indicating that some luminal lineage gene expression had been initiated during culture (Figure 1B). The propensity of MaSC/basalderived mammosphere culture to support commitment to the luminal lineage was demonstrated by the appearance of colonies with an acinar morphology identical to those derived from luminal MaPCs in Matrigel cultures (Additional file 1: Figure S1A and data not shown). Notably, global gene expression in the primary mammary epithelial subsets was more similar to mammosphere cells than to the Comma $\mathrm{D} \beta$ cell line, suggesting that primary cell-initiated mammospheres represent a more physiological screening platform than established cell lines (Figure 1B). Comparison of RNA-seq expression profiles with previously reported microarray profiles (Illumina MouseWG-6 v2.0 BeadChip platform [24]) revealed a strong correlation between the two technologies, however, RNA-seq demonstrated a greater dynamic expression range and an increased number of differentially expressed transcripts (Additional file 2: Figure S2).

To identify genes that influenced the proliferation or survival of freshly sorted MaSC/basal cells in mammosphere culture, we screened a customized mouse lentiviral library consisting of 1,295 shRNAmirs mostly targeting transcription factors and represented in 15 pools (Figure 1C). Two rounds of infection of $2 \times 10^{6}$ cells resulted in a transduction frequency of $\sim 40 \%$ (data not shown). Transduced cells were harvested at $24 \mathrm{~h}$ or 
A

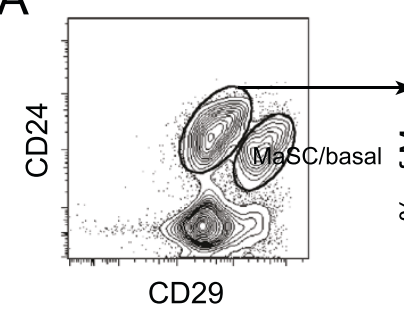

C

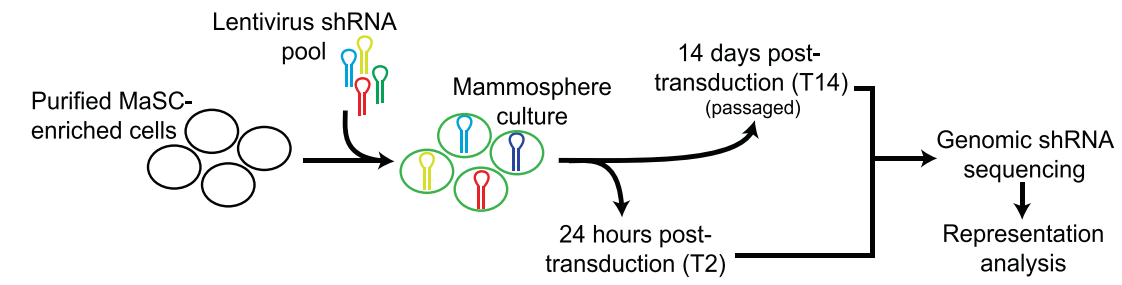

D

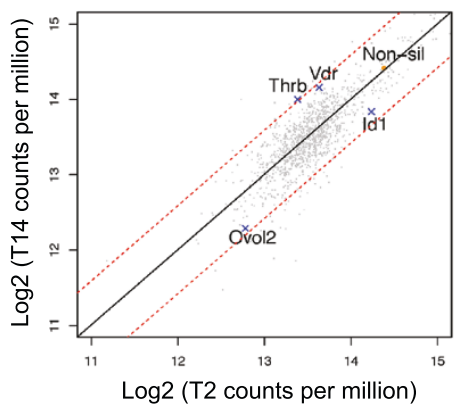

B
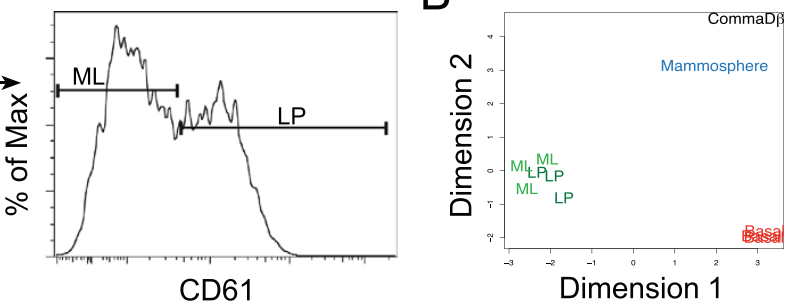

$E$

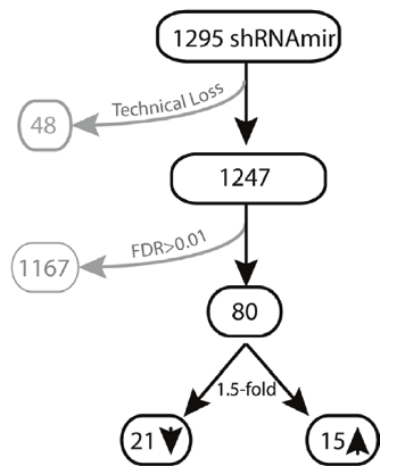

Figure 1 Differential RNA-seq expression analysis of sorted subpopulations and mammospheres and pooled shRNA screening strategy. (A) Flow cytometric profiles of $\mathrm{Lin}^{-}$mammary cell populations showing representative sort gates for CD29 ${ }^{\text {hi }} \mathrm{CD} 24^{+}$MaSC-enriched basal cells (MaSC/basal), $\mathrm{CD} 29^{\mathrm{lo}} \mathrm{CD} 24^{+} \mathrm{CD} 61^{+}$luminal progenitor-enriched cells (LP) and $\mathrm{CD} 29^{\mathrm{lo}} \mathrm{CD} 24^{+} \mathrm{CD} 61^{-}$mature luminal cell-enriched cells (ML). (B) Multidimensional scaling plot of expression data generated by RNA-Seq of populations including MaSC/basal (Basal), LP and ML populations, MaSC/ basal-derived mammospheres (Mammosphere) and Comma-D $\beta$ cells (CommaDß). (C) Schematic outline of the screening strategy. (D) Plot showing the relative frequency of shRNA-carrying cells at T2 and T14 as determined by next-generation sequencing, including a non-silencing control hairpin (non-sil). Dashed lines, 1.5-fold change. (E) Numerical summary of shRNA performance in the screen.

12 days following the second transduction, and representation of integrated shRNAs was assessed using PCR from genomic DNA and next generation sequencing. Adapter and short index sequences in the PCR primers permitted multiplexing of samples (Figure 1C). Following next generation sequencing, shRNA read counts within each indexed sample were determined and changes in shRNA frequency over time were identified in pre- and post-culture samples (Figure $1 \mathrm{C}, \mathrm{D}$ and Additional file 3: Table S1). With $0.85 \%$ of freshly isolated cells expected to give rise to primary mammospheres and assuming a $40 \%$ infection rate with a pool of 88 shRNAs, the number of interrogated mammospheres harboring a particular shRNA would be expected to be above 77 in each replicate experiment. Of note, three to five biological replicates were prepared for each of the 15 pools yielding a total of 102 samples.
From a total of 1,295 shRNAs analyzed in the screen, sequence read data was obtained for 1,247 shRNAs (Figure 1E and Additional file 3: Table S1). Eighty shRNAs targeting 73 genes significantly altered sphere growth (FDR $<0.01)$, with 15 shRNAs conferring a $>1.5$-fold growth advantage and a 21 shRNAs showing a $>1.5$-fold reduced prevalence (Figure 1D, E and Table 1). Among deleterious shRNAs were those targeting essential genes such as the TATA binding protein (Tbp), which is required for transcription (Table 1). Notably, several known regulators of mammary gland morphogenesis and/or epithelial proliferation, such as Ovol2 [25] and Id1 [26,27], were found to be significantly depleted (Figure 1D and Table 1). Moreover, basally-expressed transcription factors (Tcf4 and Lef1) that are implicated in mammary stem cell renewal through the Wnt pathway were depleted in the functional screen [28]. Although Snai2 
Table 1 Table of shRNA clones eliciting frequency changes with a FDR $\leq \mathbf{0 . 0 1}$

\begin{tabular}{|c|c|c|c|c|c|}
\hline Vendor clone ID & Gene & $\log \mathrm{FC}$ & $\log C P M$ & PValue & FDR \\
\hline V2LMM_6871 & MYOG & -2.5393 & 9.6584 & $5.24 \mathrm{E}-39$ & $4.61 \mathrm{E}-37$ \\
\hline V2LMM_68084 & ASAP1 & 1.2699 & 13.5019 & $7.53 \mathrm{E}-29$ & $6.62 \mathrm{E}-27$ \\
\hline V2LMM_63192 & LASS6 & -1.5047 & 12.8189 & $3.47 \mathrm{E}-23$ & $3.06 \mathrm{E}-21$ \\
\hline V2LMM_64405 & NROB1 & -1.2213 & 12.6156 & $3.74 \mathrm{E}-14$ & $3.29 \mathrm{E}-12$ \\
\hline V2LMM_189334 & SOX21 & 0.7841 & 14.1110 & 7.57E-11 & $6.66 \mathrm{E}-09$ \\
\hline V2LMM_82812 & Id 1 & -0.4067 & 14.0413 & $1.58 \mathrm{E}-10$ & 9.96E-09 \\
\hline V2LMM_73029 & Myst1 & -0.3976 & 13.7299 & 4.37E-10 & $1.38 \mathrm{E}-08$ \\
\hline V2LMM_62263 & TBP & -0.9262 & 6.8162 & 5.90E-10 & 2.60E-08 \\
\hline V2LMM_25195 & TCEA2 & -0.9252 & 13.0207 & $6.44 \mathrm{E}-10$ & 2.69E-08 \\
\hline V2LMM_13506 & NKX3-1 & -0.9163 & 13.0783 & $9.16 \mathrm{E}-10$ & 2.69E-08 \\
\hline V2LMM_54422 & POU1F1 & -0.9631 & 12.8253 & $1.91 \mathrm{E}-09$ & $8.39 \mathrm{E}-08$ \\
\hline V2LMM_9553 & FOXN1 & -1.0459 & 12.0477 & 8.86E-09 & $3.90 \mathrm{E}-07$ \\
\hline V2LMM_259235 & FOXC2 & 0.6794 & 11.6227 & 3.67E-08 & $1.61 \mathrm{E}-06$ \\
\hline V2LMM_53719 & TEF & -0.7084 & 12.9529 & $3.54 \mathrm{E}-08$ & 2.24E-06 \\
\hline V2LMM_27467 & NFE2L1 & -0.7027 & 12.1790 & 5.10E-08 & 2.24E-06 \\
\hline V2LMM_937 & MNT & 0.8370 & 13.6556 & 1.60E-07 & 4.71E-06 \\
\hline V2LMM_20404 & MAFG & 0.7503 & 14.4488 & 4.96E-07 & 1.09E-05 \\
\hline V2LMM_218286 & SOX9 & 0.5992 & 14.6443 & 5.34E-07 & 1.57E-05 \\
\hline V2LMM_29411 & Ezh2 & 0.3074 & 13.6843 & 1.37E-06 & $2.89 \mathrm{E}-05$ \\
\hline V2LMM_64907 & $\mathrm{NR} 1 \mathrm{H} 3$ & -0.6947 & 13.0997 & $3.26 \mathrm{E}-06$ & 5.74E-05 \\
\hline V2LMM_226932 & $\mathrm{NOTCH} 2$ & -0.7216 & 12.6071 & 7.35E-07 & 6.47E-05 \\
\hline V2LMM_22166 & $\mathrm{NR} 1 \mathrm{H} 4$ & 0.6672 & 14.0499 & 7.62E-06 & 1.12E-04 \\
\hline V2LMM_70598 & Klf4 & -0.2842 & 13.7153 & 7.81E-06 & 1.23E-04 \\
\hline V2LMM_29885 & Lmo2 & -0.2790 & 13.3138 & 1.25E-05 & 1.57E-04 \\
\hline V2LMM_85045 & ZFP449 & -0.5770 & 13.6233 & 6.17E-06 & 1.81E-04 \\
\hline V2LMM_27178 & TRPS1 & -0.7064 & 12.9042 & $9.70 \mathrm{E}-06$ & 2.13E-04 \\
\hline V2LMM_7277 & NRARP & 0.5023 & 13.3971 & 8.02E-06 & 2.35E-04 \\
\hline V2LMM_71087 & LEF1 & -0.6382 & 13.1210 & $1.87 \mathrm{E}-05$ & 2.35E-04 \\
\hline V2LMM_37331 & OVOL2 & -0.4958 & 12.5577 & 1.11E-05 & 2.45E-04 \\
\hline V2LMM_82311 & FOXJ1 & -0.4883 & 13.7075 & $1.41 \mathrm{E}-05$ & 2.48E-04 \\
\hline V2LMM_30422 & Ezh2 & 0.2667 & 13.9399 & 2.73E-05 & 2.87E-04 \\
\hline V2LMM_86479 & HLF & 0.6524 & 13.6835 & 6.89E-06 & 3.03E-04 \\
\hline V2LMM_73715 & KLF5 & -0.6192 & 12.8163 & $3.27 \mathrm{E}-05$ & 3.60E-04 \\
\hline V2LMM_77459 & Tcf4 & -0.2612 & 13.7487 & 4.01E-05 & 3.61E-04 \\
\hline V2LMM_87315 & ANKRD46 & 0.6747 & 13.9989 & 2.27E-05 & 3.99E-04 \\
\hline V2LMM_249987 & ANKRD33 & 0.5109 & 14.5653 & $1.82 \mathrm{E}-05$ & 4.00E-04 \\
\hline V2LMM_34449 & THRB & 0.6078 & 13.7210 & 4.51E-05 & 4.32E-04 \\
\hline V2LMM_34394 & MRG2 & 0.6048 & 13.8720 & 4.91E-05 & 4.32E-04 \\
\hline V2LMM_71843 & TCF19 & -0.5495 & 13.0225 & $6.03 \mathrm{E}-06$ & $5.31 \mathrm{E}-04$ \\
\hline V2LMM_162758 & ETS1 & 0.5252 & 13.3887 & $1.45 \mathrm{E}-05$ & $6.38 \mathrm{E}-04$ \\
\hline V2LMM_103225 & Rbbp8 & 0.2503 & 13.5222 & $8.51 \mathrm{E}-05$ & $6.70 \mathrm{E}-04$ \\
\hline V2LMM_3550 & TCF21 & 0.4517 & 13.0423 & 5.97E-05 & 8.76E-04 \\
\hline V2LMM_61869 & TBP & -0.6028 & 13.2274 & $3.29 \mathrm{E}-05$ & 9.64E-04 \\
\hline V2LMM_110117 & NFATC3 & -0.7358 & 13.2152 & 4.56E-05 & $1.34 \mathrm{E}-03$ \\
\hline
\end{tabular}


Table 1 Table of shRNA clones eliciting frequency changes with a FDR $\leq \mathbf{0 . 0 1}$ (Continued)

\begin{tabular}{|c|c|c|c|c|c|}
\hline V2LMM_70871 & NR113 & -0.6202 & 13.2914 & 9.95E-05 & $1.36 \mathrm{E}-03$ \\
\hline V2LMM_196851 & GATA6 & 0.6165 & 13.4939 & $1.08 \mathrm{E}-04$ & $1.36 \mathrm{E}-03$ \\
\hline V2LMM_86811 & Klf8 & -0.2331 & 14.0270 & 2.43E-04 & $1.61 \mathrm{E}-03$ \\
\hline V2LMM_14204 & $\mathrm{Cbx} 4$ & 0.2323 & 14.0165 & $2.55 \mathrm{E}-04$ & 1.61E-03 \\
\hline V2LMM_103224 & Rbbp8 & -0.2249 & 13.7322 & 4.06E-04 & 2.33E-03 \\
\hline V2LMM_2021 & MTA3 & 0.5498 & 13.3661 & 2.69E-05 & 2.37E-03 \\
\hline V2LMM_18790 & CLOCK & 0.6957 & 14.2333 & $1.13 \mathrm{E}-04$ & 2.49E-03 \\
\hline V2LMM_8902 & 2410018C20RIK & -0.4430 & 13.8888 & $1.46 \mathrm{E}-04$ & 2.57E-03 \\
\hline V2LMM_7952 & $\mathrm{NR} 2 \mathrm{C} 1$ & 0.6810 & 13.8576 & 1.57E-04 & $2.76 \mathrm{E}-03$ \\
\hline V2LMM_65378 & E2F6 & 0.4731 & 12.6660 & 9.67E-05 & 2.84E-03 \\
\hline V2LMM_14131 & Id3 & 0.2176 & 14.1862 & $6.16 \mathrm{E}-04$ & 3.23E-03 \\
\hline V2LMM_4616 & $\mathrm{Cb} \times 4$ & 0.2158 & 14.2122 & $6.73 \mathrm{E}-04$ & $3.26 \mathrm{E}-03$ \\
\hline V2LMM_81587 & Klf9 & -0.2144 & 13.9803 & 7.36E-04 & $3.31 \mathrm{E}-03$ \\
\hline V2LMM_50581 & NR2F2 & -0.5745 & 12.8242 & $3.14 \mathrm{E}-04$ & $3.45 \mathrm{E}-03$ \\
\hline V2LMM_71013 & HNRPAB & -0.5309 & 13.3310 & 8.03E-05 & 3.53E-03 \\
\hline V2LMM_71313 & CML3 & -0.6586 & 13.3786 & $2.59 \mathrm{E}-04$ & $3.80 \mathrm{E}-03$ \\
\hline V2LMM_46526 & PROX1 & 0.6463 & 13.6892 & 3.35E-04 & 4.21E-03 \\
\hline V2LMM_63443 & MAFB & -0.4007 & 13.4709 & 3.65E-04 & 4.59E-03 \\
\hline V2LMM_75410 & ASB4 & -0.3952 & 13.3161 & 4.41E-04 & 4.85E-03 \\
\hline V2LMM_87318 & ANKRD46 & 0.3883 & 13.7227 & $5.46 \mathrm{E}-04$ & $5.11 \mathrm{E}-03$ \\
\hline V2LMM_88650 & 6430502M16RIK & -0.3867 & 13.5604 & $5.81 \mathrm{E}-04$ & $5.11 \mathrm{E}-03$ \\
\hline V2LMM_194038 & HOXD8 & 0.4901 & 13.8093 & $1.84 \mathrm{E}-04$ & 5.39E-03 \\
\hline V2LMM_71230 & NR113 & -0.6275 & 12.9976 & $5.00 \mathrm{E}-04$ & $5.50 \mathrm{E}-03$ \\
\hline V2LMM_79666 & PAX8 & -0.5296 & 13.7022 & $2.58 \mathrm{E}-04$ & 5.67E-03 \\
\hline V2LMM_64571 & $\mathrm{GCDH}$ & 0.4455 & 13.2693 & $2.62 \mathrm{E}-04$ & $5.76 \mathrm{E}-03$ \\
\hline V2LMM_50262 & VDR & 0.5204 & 13.8960 & 3.27E-04 & $5.76 \mathrm{E}-03$ \\
\hline V2LMM_66887 & LASS4 & -0.4153 & 13.1732 & 3.99E-04 & 5.85E-03 \\
\hline V2LMM_71060 & GTF2H4 & -0.4379 & 13.3758 & 3.04E-04 & $6.58 \mathrm{E}-03$ \\
\hline V2LMM_5760 & MYC & 0.4271 & 13.4915 & 4.15E-04 & $6.58 \mathrm{E}-03$ \\
\hline V2LMM_6641 & PYCARD & 0.4248 & 13.2027 & 4.49E-04 & $6.58 \mathrm{E}-03$ \\
\hline V2LMM_29358 & TBX20 & -0.5067 & 13.3472 & 4.76E-04 & $6.98 \mathrm{E}-03$ \\
\hline V2LMM_212338 & PPP1R16B & 0.3734 & 13.6841 & 8.86E-04 & 7.09E-03 \\
\hline V2LMM_68781 & OTX1 & -0.6004 & 13.2971 & $8.58 \mathrm{E}-04$ & 8.39E-03 \\
\hline V2LMM_71737 & HOXA5 & 0.4088 & 13.7302 & 7.23E-04 & $9.08 \mathrm{E}-03$ \\
\hline V2LMM_67978 & LASS4 & 0.3995 & 12.8183 & $9.89 \mathrm{E}-04$ & $9.91 \mathrm{E}-03$ \\
\hline V2LMM_62940 & IRX6 & -0.3977 & 13.5485 & $1.01 \mathrm{E}-03$ & $9.91 \mathrm{E}-03$ \\
\hline
\end{tabular}

has been shown to be a positive regulator of MaSCs, it was not detected in our screen, likely reflecting inefficient knock-down by the two targeting shRNA hairpins present in the library. Conversely, we observed enrichment of shRNAs targeting genes previously associated with mammary hyperplasia in knockout mouse models including Thrb [29] and $V d r$ [30] (Figure 1D and Table 1). Several genes with reported roles in stem cell renewal and differentiation in other organ systems were also revealed by the mammosphere screen, including Prox 1 [31,32] and $\operatorname{MafB}$ [33].

To eliminate potential false-positives, RNA-seq was used to confirm the expression of candidate regulators in freshly isolated MEC subpopulations. Candidate genes with average counts per million $(\mathrm{CPM})>0.5$ were deemed to be expressed and considered potential regulators. Of 
the 73 genes targeted by shRNAs, 68 were expressed in one or more of the epithelial populations with 63 (93\%) also expressed by mammospheres (Figure 2A). Additionally, a further four genes $(6 \%)$ were expressed in mammospheres but not primary cells, indicating potential upregulation of these genes during mammosphere culture or selection of a rare cell type through culture (Figure 2A). Seven (10\%) shRNAs with a FDR $<0.01$ targeted genes that were not expressed at an appreciable level in any population, suggesting shRNA off-target effects (data not shown).

\section{In vitro validation of two candidate regulators, Asap1 and} Prox1

Two candidates, Asap1 (ARF-GAP protein with SH3 domains, ankyrin repeats and plekstrin homology domain) and Prox 1 (Prospero homeobox 1) were chosen for further study. Hairpins against either of these genes were enriched during the screen, indicating that their knock-down promoted the proliferation/survival of basal epithelial cells. Asap1 is a multi-domain member of the ARFGAP protein family and has roles in metastasis in several systems including breast cancer cell lines, in which it has been implicated in invasion and metastatic potential [34]. However, a role for Asap1 in normal developmental processes has not yet been described. Prox 1 is a homeobox transcription factor that exerts multiple roles in different organs including lineage specification [31,35] and maintenance of lineage identity, but its role in the mammary gland also remains unknown.

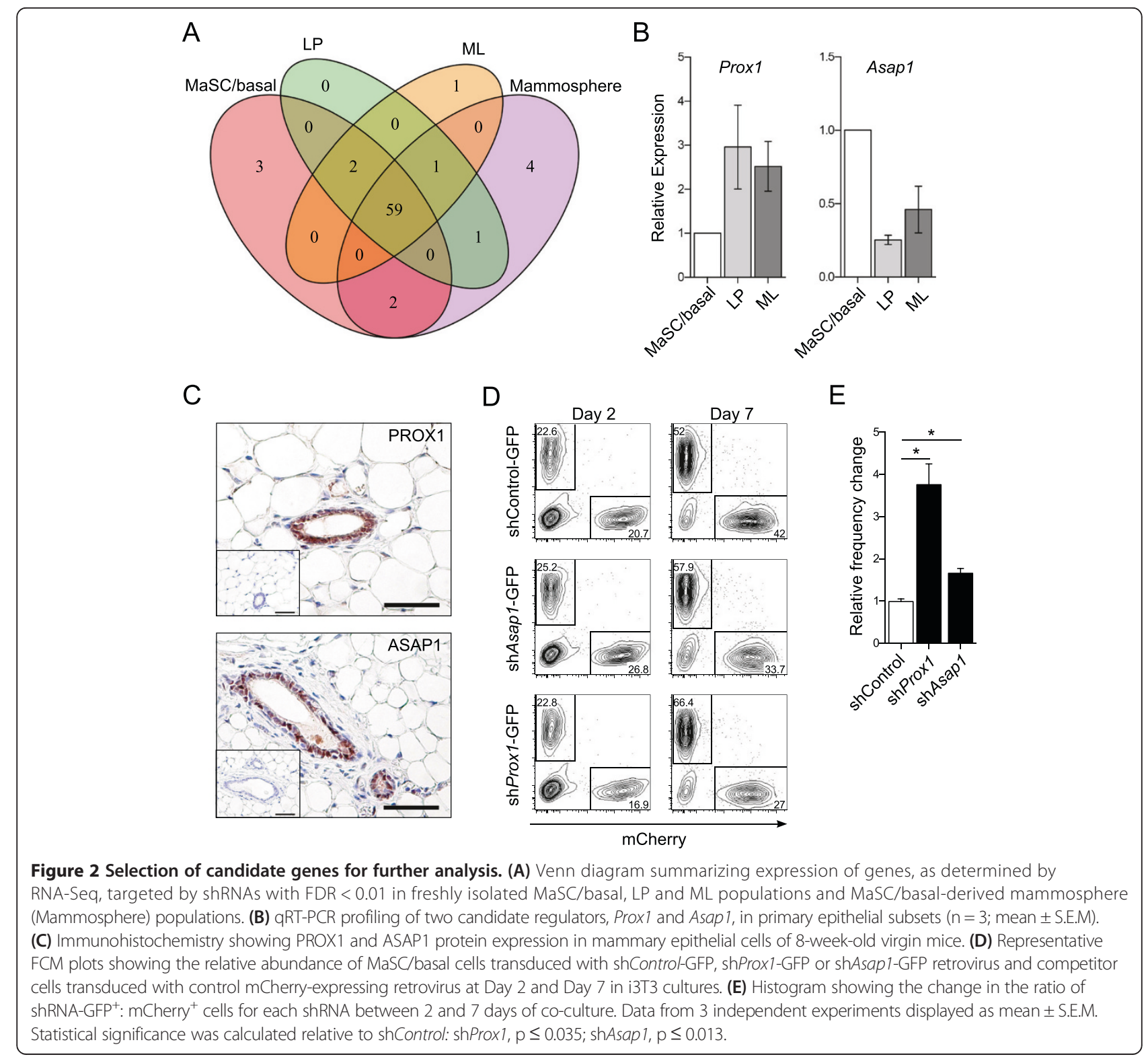


The screen demonstrated that cells carrying shAsap1 increased in frequency nearly 2.5 -fold (FDR, $7.1 \times 10^{-27}$ ) whereas shProx1-carrying cells increased more than 1.6fold (FDR, $4.2 \times 10^{-3}$; Table 1). Expression profiling confirmed that Asap1 and Prox 1 were expressed in all mammary epithelial subpopulations but showed differential expression between the MaSC/basal and luminal subpopulations (Figure 2B and $\mathrm{C}$ ). To validate shRNA representation differences observed in the screen, individual shRNAs were first evaluated in a competitive cell assay for cell growth. Over the course of 14 days in culture, the relative abundance of sorted MaSC/basal cells transduced with virus-encoded shRNA-GFP versus a reference population of $\mathrm{MaSC} / \mathrm{basal}$ cells transduced with a virus-encoded mCherry fluorescent protein was measured by flow cytometry (Figure 2D). Changes in the ratio of shRNA-GFP ${ }^{+}:$Cherry $^{+}$cells revealed the effect of shRNAs on cell 'fitness' (Figure 2D and E). To avoid potential silencing of the CMV promoter that drives shRNA and GFP expression in the pGIPZ lentiviral vector, shRNAs were re-cloned into the retroviral LMS vector, which remains active in mammary epithelial cells throughout culture and is permissive for the maintenance of stem and progenitor cells [36]. Sorted MaSC/ basal cells were plated on an irradiated NIH/3T3 (i3T3) monolayer to support their growth and then transduced. Consistent with our screen results, cells carrying $\operatorname{sh} A$ sap1 or shProx 1 were enriched during co-culture and both shRNAs stimulated colony growth at day 7 and 14 after plating (Figure $2 \mathrm{C}, \mathrm{D}$ and data not shown). The relative numbers of shRNA-GFP ${ }^{+}$cells for shProx 1 were expanded by approximately 4-fold following a short culture period of 5 days $(\mathrm{p}=0.028)$ (Figure 2D and $\mathrm{E}$ ), while shAsap1 conferred a more modest advantage of 1.5-fold $(\mathrm{p}=0.011)$ (Figure $2 \mathrm{D}$ and $\mathrm{E})$. As expected, a non-silencing control shRNA conferred no advantage on transduced cells (Figure 2D and E).

\section{Prox 1 inhibits the clonogenic potential of mammary epithelial cells}

Two shRNAs against Prox1 (shProx1-1 and shProx1-2) that reduced Prox 1 expression to below $40 \%$ of wild-type levels were selected for further clonogenic assays on i3T3 feeder layers (Figure 3A). Initially, an established regulator of mammary progenitor activity, Snai2 [37] was tested in this system using two shRNAs (shSnai2-1 and shSnai2-2) (Additional file 4: Figure S3A and B). An $80 \%$ reduction in clonogenicity was observed with these hairpins, supporting the efficacy of knockdown and clonogenic readout in this system (Additional file 4: Figure S3C). Cells carrying either Prox 1 shRNA demonstrated $\mathrm{a} \sim$ two-fold higher clonogenicity than those carrying a non-silencing control shRNA (Figure 3B). Transplantation of MaSC/basal cells transduced with

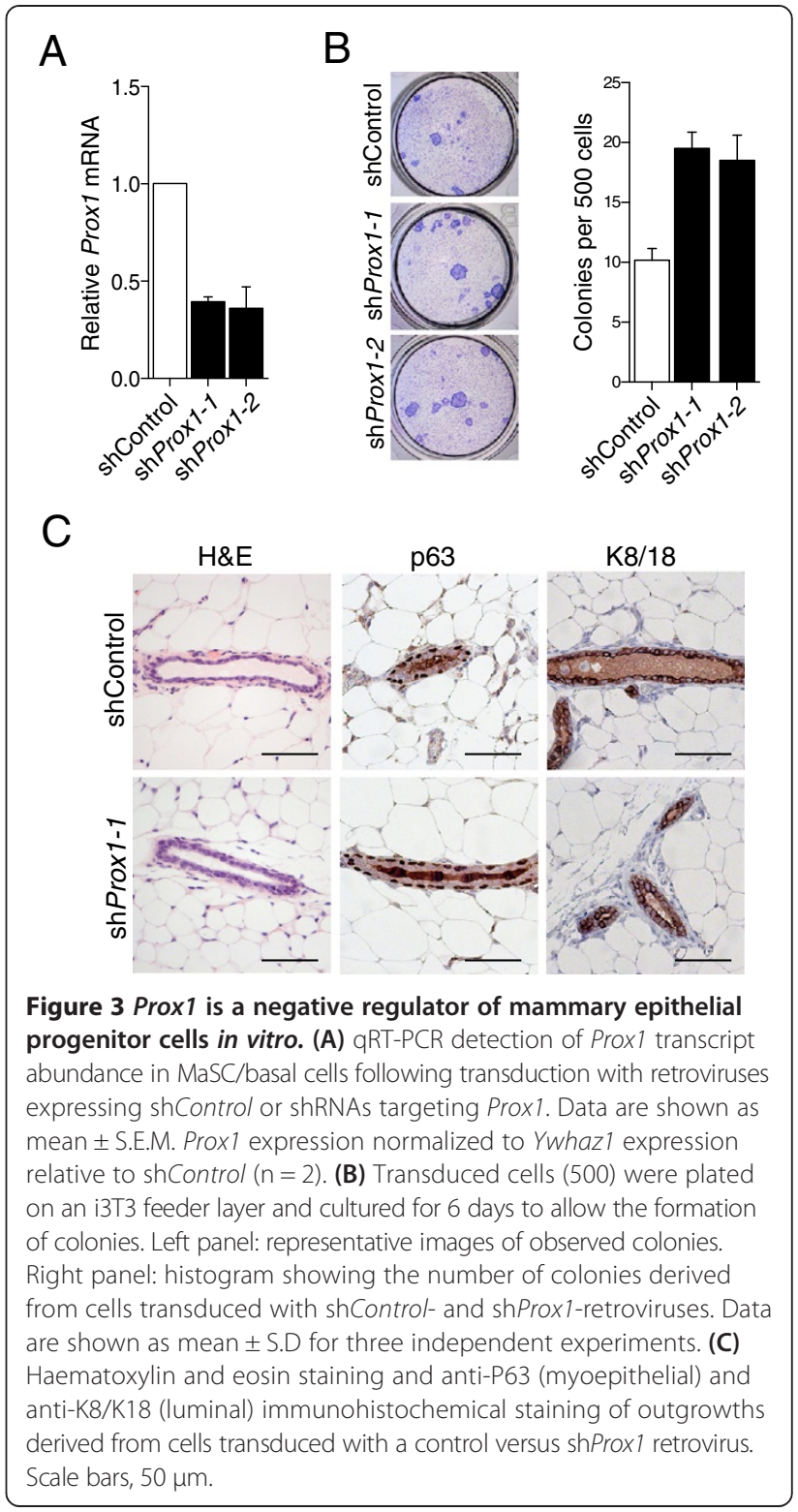

shProx1-expressing retroviruses yielded outgrowths with normal morphology and did not reveal any difference in repopulating frequency compared to control cells (Figure $3 \mathrm{C}$ and data not shown). These findings suggest that Prox 1 levels are less critical for the activity of MaSCs than MaPCs, although the effect of reducing Prox 1 expression to even lower levels is yet to be determined.

\section{Asap1 suppresses mammary stem and progenitor cell numbers or activity}

Two independent shRNAs that reduced Asap1 expression to approximately $25 \%$ of wild-type levels (Figure 4A) were used to confirm a role for Asap1 in normal primary mammary epithelial cells. Transduction of MaSC/basal 
A

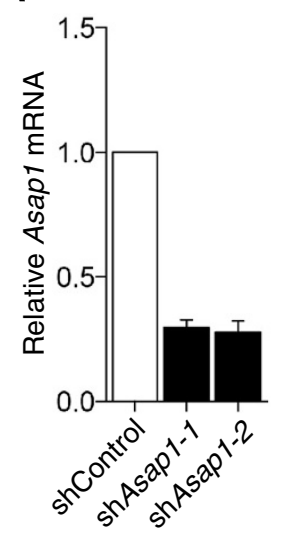

C

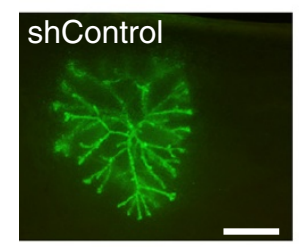

\section{shAsap 1-1}

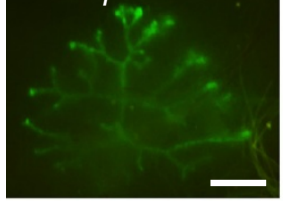

E

\begin{tabular}{|c|c|c|c|c|}
\hline shRNA & $\begin{array}{l}\text { Transplanted } \\
\text { cell dose }\end{array}$ & $\begin{array}{l}\text { Outgrowths I } \\
\text { Transplants }\end{array}$ & \% MFP Filling & $\begin{array}{l}\text { MRU Frequency } \\
(95 \% \mathrm{Cl})\end{array}$ \\
\hline shControl & $\begin{array}{c}15,000 \\
10,000 \\
5,000 \\
3,000 \\
1,000 \\
200\end{array}$ & $\begin{array}{c}7 / 7 \\
2 / 4 \\
10 / 12 \\
4 / 4 \\
13 / 18 \\
\\
5 / 8\end{array}$ & & $\begin{array}{c}1 / 1925 \\
(1 / 1210-1 / 3063)\end{array}$ \\
\hline shAsap1-1 & $\begin{array}{c}15,000 \\
10,000 \\
5,000 \\
3,000 \\
1,000 \\
\\
200\end{array}$ & $\begin{array}{c}8 / 8 \\
4 / 4 \\
13 / 13 \\
5 / 6 \\
21 / 22 \\
\\
8 / 8 \\
\end{array}$ & & $\begin{array}{c}1 / 633 \\
(1 / 232-1 / 633)\end{array}$ \\
\hline
\end{tabular}

B
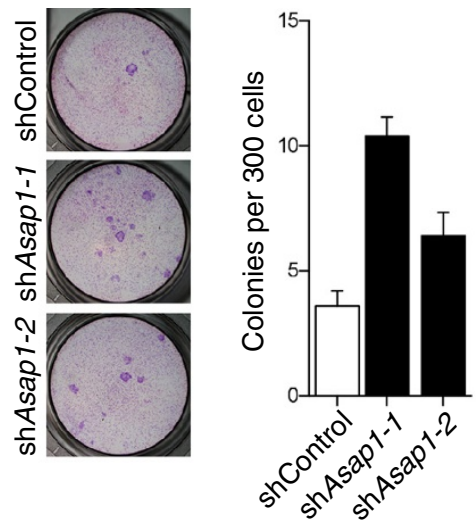

D

$H \& E$

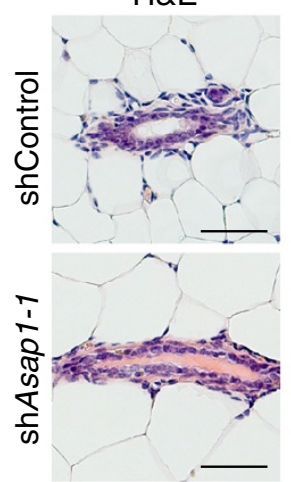

p63

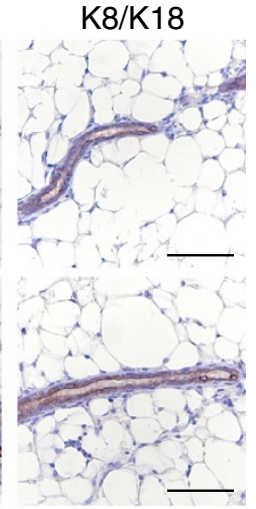

Figure 4 (See legend on next page.) 
(See figure on previous page.)

Figure 4 Asap1 negatively regulates mammary stem and progenitor cells. (A) Quantitative RT-PCR detection of Asap1 transcript abundance in MaSC/basal cells following transduction with retroviruses expressing shControl or shRNAs targeting shAsap1. Data are shown as mean \pm S.E.M. $(n=3)$. Prox 1 expression is normalized to Ywhazl expression relative to shControl. (B) Left panel: transduced cells were plated on an i3T3 feeder layer and cultured for 6 days to allow the formation of colonies. Right panel: histogram showing the number of colonies derived from shControl- and shAsap 1-transduced cells. Data are shown as mean \pm S.D for 3 independent experiments. (C) Representative whole-mount images of GFP ${ }^{+}$outgrowths derived from transplantation of shControl- or shAsap1-retrovirally transduced MaSC/basal cells. Scale bar, $2 \mathrm{~mm}$. (D) Morphological analysis of outgrowths. Haematoxylin and eosin staining and immunohistochemical staining for P63 and K8/K18 of outgrowths following transplantation. Scale bars, $50 \mu \mathrm{m}$. (E) Table of limiting dilution analysis of transplantation frequencies of MaSC/basal cells transduced with shControl or shAsap1 retroviruses. The number of transplants and resulting outgrowths is shown as well as the extent of fat pad filling by individual outgrowths.

cells with either shAsap1-1 or shAsap1-2 retrovirus resulted in higher progenitor numbers compared to control cells in 2D clonogenic assays (Figure 4B), confirming a role for Asap1 in progenitor cells. Transplantation of shAsap1-transduced cells into clear fat pads revealed a greater than 3-fold higher repopulation frequency compared to shControl virus-infected cells (Figure 4C). Branched $\mathrm{GFP}^{+}$outgrowths were morphologically similar to those transduced with shControl retrovirus and exhibited a similar degree of fat-pad filling (Figure 4C). The typical architecture of these outgrowths was confirmed by immunohistochemical staining, with an outer layer of myoepithelial cells expressing p63 and SMA, and a luminal cell layer expressing Cytokeratin 8/18 and E-Cadherin (Figure 4D and data not shown). Moreover, outgrowths derived from Asap1 knock-down cells were capable of full differentiation to milk-producing alveoli when recipients were subject to pregnancy (data not shown).

\section{Discussion}

In this study, we have developed a protocol to identify novel regulators of mammary stem/progenitor cells using freshly isolated MaSC-enriched cells for a functional RNAi screen based on pooled shRNA libraries. Based on three independent biological screens, we identified shRNAs targeting 73 genes as potential modulators of stem/progenitor cell behavior with more than half of those targeting novel genes that have not been previously implicated in mammary gland development. Although the changes were modest, they were highly reproducible. Notably, the strategy also identified a number of known regulators of stem and progenitor cells, thereby validating the screening strategy. The mammosphere assay primarily reads out progenitor activity, given that the transplantation frequency of mammosphere cultures is approx. 1 in 300 (read-out for stem cells) whereas the colony-forming potential of these cells is around 1 in 20 (read-out for stem/progenitor cells). The system established here should be immediately applicable to future sgRNA/CRISPR libraries using pooled screens [38].
Potential limitations associated with this and other shRNA-based functional screens, include poor coverage of genes by multiple shRNAs (in this case a mean shRNA per gene of 2; mode, 1), and incomplete knockdown of gene expression. The observed modest fold changes in part reflect the use of primary cells in a short-term mammosphere assay, which is necessary to obviate any changes associated with prolonged culture of epithelial cells, resulting in smaller amounts of material post-culture relative to that obtained from the use of established cell lines. It is noteworthy that the foldchanges observed here are comparable to those observed in another in vitro shRNA screen at early time-points [17].

Further exploration of two genes with verified expression in the mammary gland, Asap1 and Prox1, revealed roles in regulating mammary basal progenitor activity. Retrovirus-mediated knockdown of either gene augmented progenitor cell numbers in colony forming assays in vitro. Moreover, knockdown of Asap1 expression led to a significant increase in the repopulating frequency, suggesting that Asap1 either negatively regulates MaSC numbers or their activity. Conversely, knockdown of Prox 1 did not affect mammary repopulating potential, either suggesting that Prox 1 does not compromise MaSC function or that complete knock-down of this gene is required for an overt phenotype. In other organs, there is evidence that Prox 1 regulates stem and/or progenitor cell activity in a context-dependent fashion (reviewed in [39]). Interestingly, both genes have been postulated to contribute to oncogenesis when overexpressed. ASAP1 has been shown to be necessary for the in vitro invasive potential and in vivo metastatic potential of specific breast cancer cell lines including MDA-MB-231 cells (Onodera et al., 2005), while increased Prox1 expression promotes the transition of intestinal adenomas to highgrade dysplasia or carcinoma in situ [40]. Additional experiments using inducible gene knock-out strategies or CRISPR/Cas9 technology to further reduce or ablate ASAP1 or PROX1 protein levels will be required to clarify the specific effects of these genes on distinct mammary cell populations during normal development and to elucidate their roles in breast oncogenesis. 


\section{Methods}

Mammary cell preparation and cell culture

The preparation of mammary epithelial cell suspensions from 8-10 week-old FVB/N female mice and flow cytometric purification has been described [1]. Unless otherwise stated, all chemicals and media components were purchased from Life Technologies (Carlsbad, CA, USA) or Sigma (St Louis, MO, USA). For mammosphere culture, cells were plated in ultra-low adherence plates (Corning) in mammosphere medium (DMEM/F12 + Glutamax, 1\% penicillin/streptomycin, $10 \mathrm{ng} / \mathrm{ml} \mathrm{EGF}$, $10 \mathrm{ng}$ bFGF, $5 \mu \mathrm{g} / \mathrm{ml}$ insulin, $0.5 \mu \mathrm{g} / \mathrm{ml}$ hydrocortisone, B27 supplement) at 100,000 cells/ml and maintained as suspension cultures. Medium was exchanged every 3-4 days and spheres were passaged using trypsin-EDTA and gentle trituration every 7 days before replating at a density of not greater than 50,000 cells $/ \mathrm{ml}$. For irradiated NIH/3T3 (i3T3) co-culture, cells were counted manually and plated in tissue culture plates with i3T3 fibroblasts (5,000 Rads) in mammary growth medium (DMEM/F12 with glutamax, $1 \%$ penicillin/streptomycin, $10 \mathrm{ng} / \mathrm{ml}$ EGF, $5 \mu \mathrm{g} / \mathrm{ml}$ insulin, $0.5 \mu \mathrm{g} / \mathrm{ml}$ hydrocortisone, $20 \mathrm{ng} /$ $\mathrm{ml}$ cholera toxin) with $5 \%$ FCS. After overnight incubation at $37^{\circ} \mathrm{C}$ in $5 \% \mathrm{O}_{2} / 5 \% \mathrm{CO}_{2}$, the cultures were changed to the same medium containing 1\% FCS and incubated for a further 5 days. Colonies were harvested with trypsin/EDTA for sorting or stained with Giemsa for imaging and colony enumeration. For 3D colony assays, transduced cells were mixed with Matrigel (BD Biosciences, San Jose, CA) and cultured as described $[1,11]$. Cultures were imaged before fixation with $4 \%$ paraformaldehyde and embedded in paraffin. CommaD $\beta$ cells were maintained as previously described [23].

\section{Transplantation and mammary gland outgrowth analysis} GFP-expressing transduced cells sorted by flow cytometry were manually counted and transplanted at limiting dilution as described [1], in the presence of $25 \%$ growth factor-reduced Matrigel. GFP ${ }^{+}$outgrowths were visualized using a dissecting microscope (Leica Microsystems Gmbh, Wetzlar, Germany) and histology performed as described [3]. Mammary fat pad filling was quantitated comparing total fat pad area and outgrowth area using Image J software. All animal experiments conformed to regulatory standards and were approved by the Walter and Eliza Hall Institute (WEHI) Animal Ethics Committee.

\section{Lentivirus production and transduction}

A library of GIPZ plasmids expressing shRNAs was expanded individually in bacteria, then clones were pooled and plasmids purified yielding 15 pools of 90 shRNAs (Open Biosystems Transcription Factors Gene Family Library cat\#RMM4950) and one pool of 63 shRNAs (Open Biosystems, custom order WEHI_73597).
Lentivirus production was initiated by calcium phosphate transfection of 293T cells with pGIPZ shRNA-containing vectors and pMD2.G and psPAX2 (Addgene plasmids 12259 and 12260). Viral supernatants were collected at 26 and $44 \mathrm{hr}$ post-transfection and concentrated via ultracentrifugation as per manufacturer's protocol. Pellets were resuspended in mammary growth medium with 5\% FCS, centrifuged at maximum speed for 5 minutes at room temperature to remove most serum proteins. Supernatant containing $100 \times$ concentrated virus stored at $-80^{\circ} \mathrm{C}$. The titre of each frozen virus stock was assessed biologically. Briefly, the day prior to transduction, 50,000 293T cells were seeded into 12-well plates in 293T medium (DMEM with $10 \%$ FCS and 1\% penicillin/streptomycin). On the day of transduction, cells in three wells were counted to determine the number of cells present at transduction. Dilutions of virus made in 293T medium containing $5 \mu \mathrm{g} / \mathrm{ml}$ polybrene were used to replace the medium on remaining wells so that a series of wells were exposed to decreasing quantities of virus. Following transduction for $16-24 \mathrm{hr}$, the medium was changed and $48 \mathrm{hr}$ later, cells were analyzed for GFP expression by flow cytometry. The number of cells at transduction and the amount of virus added to a well, where the percentage of $\mathrm{GFP}^{+}$ cells was between 1 and 20\%, was used to calculate the transducing units (TU) per $\mathrm{ml}$ using the following formula: [Number of cells at transduction $\times\left(\% \mathrm{GFP}^{+}\right.$cells/ 100)]/volume of virus (ml). Typical TU of $1 \times 10^{8} / \mathrm{ml}$ were achieved. For mammosphere transduction, $2 \times 10^{6}$ purified cells were plated in mammosphere medium containing $5 \mu \mathrm{g} / \mathrm{ml}$ polybrene and transduced at 0 and $16 \mathrm{hr}$ with $4 \times 10^{6} \mathrm{TU}$. Medium was exchanged after $24 \mathrm{hr}$ and a sample of the culture was taken for analysis of baseline shRNA frequency (time-point T2). Following 14 days in culture, the remaining cells were harvested (T14).

\section{Retrovirus cloning, production and transduction}

The LMS vector into which the non-silencing, and targeting shRNAs were cloned has been described [41] and the LMS-shControl, containing a non-specific shRNA sequence, was obtained from Open Biosystems. Other shRNA templates were designed as described and PCR amplified from DNA oligonucleotides using the forward primer 5'-CAGAAGGCTCGAGAAGGTATATTGCTGT TGACAGTGAGCG-3' and the reverse primer 5'-CTA AAGTAGCCC C TTGAATTCCGAGGCAGTAGGCA-3' [42]. Alternatively, shRNAs were purchased from OpenBiosystems as pGIPZ clones. In both cases, 137 bp shRNA products were isolated using EcoRI and XhoI digestion and subcloned into the LMS vector. Mature anti-sense sequences were as follows: shAsap1-1 (Open Biosystems clone V3LMM_492766), 5'-TTCGTCGTCATTATCTG CCTGG-3'; shAsap1-2, 5'-ATATTATATAAGTCAGCA 
GCCA-3'; shProx1-1 (Open biosystems clone V3LMM_ 506363), 5'-TTCTCTGTAACTTTCTCGG-3'; shProx12 (Open Biosystems clone V3LMM_506365), 5'-TTC ACTCCAATGTCAACCC-3'; shSnai2-1 described previously [43]; shSnai2-2 5'-CGCAGACCCACTCTGAT GTAA-3'. For production of retroviruses, Phoenix cells $(10 \mathrm{~cm}$ plates) were transfected with $5 \mu \mathrm{g}$ of vector using calcium phosphate precipitation and the virus supernatant was collected and filtered through a $0.45 \mu \mathrm{m}$ filter at 48 and $72 \mathrm{hr}$. For transduction, cells on feeder layers in 6 well-plates were spin infected $\left(2,500 \mathrm{rpm}, 32^{\circ} \mathrm{C}, 1 \mathrm{hr}\right)$ with $2 \mathrm{ml}$ of viral supernatant per well containing $5 \mu \mathrm{g} / \mathrm{ml}$ polybrene. Two to four days after transduction, transduced $\mathrm{GFP}^{+}$or $\mathrm{mCherry}^{+}$cells were purified by flow cytometry.

\section{Immunohistochemistry}

Paraffin-embedded sections $(5 \mu \mathrm{m})$ were subjected to antigen retrieval using either $10 \mathrm{mM}$ citrate buffer $\mathrm{pH} 6$ or Tris-EDTA buffer pH9, then blocked before staining with primary antibodies overnight at $4^{\circ} \mathrm{C}$ and incubation with a biotinylated secondary antibody at RT for $30 \mathrm{~min}$. The streptavidin-based peroxidase detection system (ABC reagent, Vector Laboratories, Burlingame, $\mathrm{CA}$ ) was used with 3,3-diaminobenzidine as substrate (DAKO, Glostrup, Denmark). In all cases, an isotype- matched control IgG was used as a negative control.

\section{Antibodies}

For flow cytometry, antibodies against mouse antigens were purchased from Biolegend (San Diego, CA) or BD Biosciences (Franklin Lakes, NJ) unless otherwise specified and included CD24-PE (M1/69), CD31-B (MEC13.3), TER-119-B (TER-119), CD45-B (30-F11), CD29-FITC (HMB1-1), CD61-APC and streptavidin-APC-Cy7. For immunohistochemistry, the following antibodies were used: anti-SMA (1A4; Sigma), anti-p63 (4A4), K8/18 (Troma-1; Developmental Studies Hybridoma Bank, Iowa City), anti-Keratin 5 (Covance, Emeryville, CA), anti-Keratin 14 (LL002; Novocastra, UK), anti-E-cadherin, anti-ASAP1 (Rockland Immunochemicals Inc., Limerick, PA), antiPROX1 (ab37128; Abcam, Cambridge, UK), anti-SNAI2 (\#9585 Cell Signaling Technology, Massachussetts, USA). Secondary antibodies included biotin-conjugated goat anti-rabbit IgG, rabbit anti-rat IgG and goat anti-mouse IgG (Vector Laboratories, Burlingame, CA).

\section{shRNA amplicon sequencing and analysis}

Genomic DNA was extracted using the DNeasy Blood kit (Qiagen) from samples taken at T0 and T2 timepoints and shRNA sequences were isolated from 200$800 \mu \mathrm{g}$ gDNA (routinely $400 \mu \mathrm{g}$ ) using the PCR protocol outlined below. Primers were common to all shRNAs. The Forward primer, 5'-CAAGCAGAAGACGGCATAC
GA GCTCT TCCGATCTTAGTGAAGCCACAGATGT A-3' anneals in the loop region and incorporates the P7 Illumina adapter sequence. The Reverse primer (5'-AAT GATACGGCGACCACCGAGATCTACACTCTTTCCC TACACGACGC TC TTCCGATCTXXXXXGTAGCCCC TTGAATTCCGAG-3') anneals in a region common to all shRNAs and incorporates a variable $5 \mathrm{bp}$ index to enable multiplexing of samples, the P5 Illumina adapter sequence and the sequencing primer site. Following one round of PCR with an annealing temperature of $52^{\circ} \mathrm{C}$ and a further 30 to 32 cycles with an annealing temperature of $55^{\circ} \mathrm{C}$, indexed, half shRNA products (168 bp) were pooled and sequenced on an Illumina GAIIx or HiSeq2000. Processing of the raw sequence reads was carried out in $\mathrm{R}$ as described previously [38]. Briefly, the number of perfect matches for each indexhairpin combination was tallied to give counts for the relevant hairpins in each sample. Downstream statistical analysis of the summarized counts was performed using the edgeR software (version 2.6.3) [44]. Outlier samples determined by visual inspection of multidimensional scaling plots were removed. An exact test for differences between the T14 and T2 biological replicate samples in each pool of shRNA was performed assuming a negative binomial distribution of the counts [45] and a common dispersion estimate. Log2-fold-changes, $\mathrm{p}$-values and false discovery rates for each shRNA were reported.

\section{RNA-seq analysis}

Total RNA was extracted and purified from: (1) sorted luminal or basal populations from the mammary glands of female virgin 8-10 week-old FVB/N mice (three independent samples for population), (2) MaSC/basal cells cultured for 1 week under mammosphere conditions, and (3) Comma D $\beta$ cells grown under maintenance conditions [23]. Total RNA (100 ng) was used to generate sequencing libraries for whole transcriptome analysis following the Illumina's TruSeq RNA v2 sample preparation protocol. Completed libraries were sequenced on HiSeq 2000 with TruSeq SBS Kit v3- HS reagents (Illumina) as $100 \mathrm{bp}$ single-end reads at the Australian Genome Research Facility (AGRF), Melbourne. An average of 62 million $100 \mathrm{bp}$ single-end reads were obtained per sample. Reads were aligned to the mouse reference genome (mm10) using the Rsubread package (version 1.14.1) [46] and assigned to genes using the featureCounts method [47]. Data were TMM normalized [48] and transformed into $\log 2$ counts per million. Linear models with observational-level weights [49] were fitted to obtain average expression values for each gene in each sample type and moderated t-statistics were used to assess differential expression between populations [50] using the limma package (version 3.20.5) [51]. False discovery rates [52] were used together with log2-fold- 
changes to rank genes. These data are available through GEO Series accession number GSE63310.

For comparison of gene expression across platforms, previously published microarray data (GSE19446) [24] were compared with RNA-seq profiles. Where multiple probes were available for a given gene, the probe with the highest average expression level was taken as representative. Genes were matched between platforms using gene symbols and respective log2-fold changes were plotted.

\section{Statistical analysis}

Statistical analysis was performed using GraphPad Prism software (GraphPad, San Diego, CA). Data are shown as mean \pm standard error of the mean (S.E.M.) or standard deviation (S.D.), where appropriate. Where applicable, the Student's $t$-test was used, with $\mathrm{p}<0.05$ considered statistically significant.

\section{Additional files}

Additional file 1: Figure S1. MaSC/basal-derived mammosphere culture is permissive for the retention of progenitor and stem cell activity. (A) MaSC/basal cells cultured under mammosphere conditions generate multiple colony types including those with a luminal acinar morphology in Matrigel (arrowheads) Scale bar, $1 \mathrm{~mm}$. (B) A carmine-alum stained whole-mounted mammary epithelial tree formed following transplantation of $500 \mathrm{MaSC} / \mathrm{basal}$-derived mammosphere cells into a mammary fat pad pre-cleared of endogenous epithelium. (C) Table of limiting dilution analysis of transplanted mammosphere cells.

Additional file 2: Figure S2. Comparison between RNA-Seq expression profiles of primary mammary epithelial cell populations with the Illumina MouseWG-6 v2.0 BeadChip dataset. Plots showing differential expression of genes in the MaSC/basal versus luminal progenitor (LP) subset, MaSC/ basal versus mature luminal (ML) cell subset and LP versus ML subset, as determined by microarray [24] and RNA-Seq. Genes differentially expressed with log2-fold-change $>2$ and FDR $<0.001$ were enumerated with those identifiable by both platforms highlighted in blue, RNA-Seq-only in yellow and microarray-only in red.

Additional file 3: Table S1. Table of shRNA clones included in the screen. Additional file 4: Figure S3. Snai2 is a positive regulator of mammary epithelial progenitor cells in vitro. (A) qRT-PCR detection of Snai2 transcript abundance in MaSC/basal cells following transduction with retroviruses expressing shControl or shRNAs targeting Snai2. Data are shown as mean \pm S.D. Snai2 expression normalized to Gapdh expression is shown relative to shControl $(n>3)$. (B) Western blot analysis of Snai2 protein in MaSC/basal cells following transduction with retroviruses expressing shControl or shRNAs targeting Snai2. (C) Transduced cells (500) were plated on an i3T3 feeder layer and cultured for 6 days to allow the formation of colonies. Left panel: histogram showing the number of colonies derived from cells transduced with shControl- and shSnai2-retroviruses. Data are shown as mean \pm S.D for three independent experiments. Right panel: representative images of observed colonies. Scale bar, $0.5 \mathrm{~cm}$.

\section{Competing interests}

The authors declare that they have no competing interests.

\section{Authors' contributions}

JMS: Design, collection of data and interpretation, writing of manuscript; MER and GKS: Bioinformatic analyses; SAB: Snai2 assays; KJ and TJB: assistance with cell sorting; FV: Transplantation assays; KL: assistance with immunostaining; RAD: Assistance with experimental design; GJL and JEV: Assistance with experimental design and manuscript writing. All authors read and approved the final manuscript.

\section{Acknowledgements}

The authors would like to thank M. Wakefield for assistance with experimental design, K. Breslin for technical assistance, S. Taoudi and N Harvey for helpful discussion, and the Animal, FACS, Imaging and Histology facilities at WEHI. This work was supported by the Australian National Health and Medical Research Council (NHMRC) grants \#461221, \#1016701; NHMRC IRIISS; the Victorian State Government through VCA funding of the Victorian Breast Cancer Research Consortium and Operational Infrastructure Support; and the Australian Cancer Research Foundation. R.A.D was supported by a Victorian Endowment for Science, Knowledge, and Innovation (VESKI) Fellowship, G.K.S. and G.J.L. by NHMRC Fellowships (\#1058892 and \#637307, respectively); and J.E.V. by an Australia Fellowship.

\section{Author details}

${ }^{1}$ ACRF Stem Cells and Cancer Division, The Walter and Eliza Hall Institute of Medical Research, 1 G Royal Parade, Parkville, VIC 3052, Australia. ${ }^{2}$ Molecular Genetics of Cancer Division, The Walter and Eliza Hall Institute of Medical Research, 1G Royal Parade, Parkville, VIC 3052, Australia. ${ }^{3}$ Bioinformatics Division, The Walter and Eliza Hall Institute of Medical Research, 1G Royal Parade, Parkville, VIC 3052, Australia. ${ }^{4}$ Molecular Medicine Division, The Walter and Eliza Hall Institute of Medical Research, 1G Royal Parade, Parkville, VIC 3052, Australia. ${ }^{5}$ Department of Medical Biology, The University of Melbourne, Parkville, VIC 3010, Australia. ${ }^{6}$ School of Mathematics and Statistics, The University of Melbourne, Parkville, VIC 3010, Australia. ${ }^{7}$ Department of Medicine, The University of Melbourne, Parkville, VIC 3010, Australia. ${ }^{8}$ Department of Medical Oncology, The Royal Melbourne Hospital, Grattan Street, Parkville, VIC 3050, Australia.

Received: 12 March 2015 Accepted: 12 March 2015

Published online: 03 April 2015

\section{References}

1. Shackleton M, Vaillant F, Simpson KJ, Stingl J, Smyth GK, Asselin-Labat M-L, et al. Generation of a functional mammary gland from a single stem cell. Nature. 2006:439:84-8.

2. Stingl J, Eirew P, Ricketson I, Shackleton M, Vaillant F, Choi D, et al. Purification and unique properties of mammary epithelial stem cells. Nature. 2006;439:84-8

3. Asselin-Labat M-L, Sutherland KD, Barker $H$, Thomas $R$, Shackleton M, Forrest NC, et al. Gata-3 is an essential regulator of mammary-gland morphogenesis and luminal-cell differentiation. Nat Cell Biol. 2007;9:201-9.

4. Asselin-Labat M-L, Sutherland KD, Vaillant F, Gyorki DE, Wu D, Holroyd S, et al. Gata-3 negatively regulates the tumor-initiating capacity of mammary luminal progenitor cells and targets the putative tumor suppressor caspase-14. Mol Cell Biol. 2011;31:4609-22.

5. Sleeman KE, Kendrick H, Robertson D, Isacke CM, Ashworth A, Smalley MJ. Dissociation of estrogen receptor expression and in vivo stem cell activity in the mammary gland. J Cell Biol. 2007;176:19-26.

6. Shehata M, Teschendorff A, Sharp G, Novcic N, Russell IA, Avril S, et al. Phenotypic and functional characterisation of the luminal cell hierarchy of the mammary gland. Breast Cancer Res. 2012;14(5):R134.

7. Rios AC, Fu NY, Lindeman GJ, Visvader JE. In situ identification of bipotent stem cells in the mammary gland. Nature. 2014;506:322-7.

8. Wang D, Cai C, Dong X, Yu QC, Zhang X-O, Yang L, et al. Identification of multipotent mammary stem cells by protein $C$ receptor expression. Nature. 2014:517:81-4.

9. Van Keymeulen A, Rocha AS, Ousset M, Beck B, Bouvencourt G, Rock J, et al. Distinct stem cells contribute to mammary gland development and maintenance. Nature. 2011:479:189-93.

10. van Amerongen $\mathrm{R}$, Bowman AN, Nusse R. Developmental stage and time dictate the fate of Wnt/ $\beta$-catenin-responsive stem cells in the mammary gland. Cell Stem Cell. 2012;11:387-400.

11. Visvader JE, Stingl J. Mammary stem cells and the differentiation hierarchy: current status and perspectives. Genes Dev. 2014;28:1143-58.

12. Silva JM, Marran K, Parker JS, Silva J, Golding M, Schlabach MR, et al. Profiling essential genes in human mammary cells by multiplex RNAi screening. Science. 2008;319:617-20.

13. Simpson KJ, Selfors LM, Bui J, Reynolds A, Leake D, Khvorova A, et al. Identification of genes that regulate epithelial cell migration using an siRNA screening approach. Nat Cell Biol. 2008;10:1027-38. 
14. Wolf J, Dewi D, Fredebohm J, Müller-Decker K, Flechtenmacher C, Hoheisel JD, et al. A mammosphere formation RNAi screen reveals that ATG4A promotes a breast cancer stem-like phenotype. Breast Cancer Res. 2013;15:R109.

15. Garimella SV, Gehlhaus K, Dine JL, Pitt JJ, Grandin M, Chakka S, et al. Identification of novel molecular regulators of tumor necrosis factor-related apoptosis-inducing ligand (TRAIL)-induced apoptosis in breast cancer cells by RNAi screening. Breast Cancer Res. 2014;16:1-21.

16. Berns N, Woichansky I, Friedrichsen S, Kraft N, Riechmann V. A genome-scale in vivo RNAi analysis of epithelial development in Drosophila identifies new proliferation domains outside of the stem cell niche. J Cell Sci. 2014;127:2736-48.

17. Chen T, Heller E, Beronja S, Oshimori N, Stokes N, Fuchs E. An RNA interference screen uncovers a new molecule in stem cell self-renewal and long-term regeneration. Nature. 2012;485:104-8.

18. Deneault E, Cellot S, Faubert A, Laverdure J-P, FrEchette M, Chagraoui J, et al. A functional screen to identify novel effectors of hematopoietic stem cell activity. Cell. 2009;137:369-79.

19. Schramek D, Sendoel A, Segal JP, Beronja S, Heller E, Oristian D, et al. Direct in vivo RNAi screen unveils myosin lla as a tumor suppressor of squamous cell carcinomas. Science. 2014;343:309-13.

20. Dontu G, Jackson KW, McNicholas E, Kawamura MJ, Abdallah WM, Wicha MS. Role of Notch signaling in cell-fate determination of human mammary stem/progenitor cells. Breast Cancer Res. 2004;6:R605-15.

21. Cicalese A, Bonizzi G, Pasi CE, Faretta M, Ronzoni S, Giulini B, et al. The tumor suppressor p53 regulates polarity of self-renewing divisions in mammary stem cells. Cell. 2009;138:1083-95.

22. Dontu G. In vitro propagation and transcriptional profiling of human mammary stem/progenitor cells. Genes Dev. 2003;17:1253-70.

23. Deugnier M-A, Faraldo MM, Teulière J, Thiery JP, Medina D, Glukhova MA. Isolation of mouse mammary epithelial progenitor cells with basal characteristics from the Comma-D $\beta$ cell line. Dev Biol. 2006;293:414-25.

24. Lim E, Wu D, Pal B, Bouras T, Asselin-Labat M-L, Vaillant F, et al. Transcriptome analyses of mouse and human mammary cell subpopulations reveal multiple conserved genes and pathways. Breast Cancer Res. 2010;12:R21.

25. Watanabe K, Villarreal-Ponce A, Sun P, Salmans ML, Fallahi M, Andersen B, et al. Mammary morphogenesis and regeneration require the inhibition of EMT at terminal end buds by Ovol2 transcriptional repressor. Dev Cell. 2014;29:59-74.

26. Shin D-H, Jang S-H, Kang B-C, Kim H-J, Oh SH, Kong G. Constitutive overexpression of Id- 1 in mammary glands of transgenic mice results in precocious and increased formation of terminal end buds, enhanced alveologenesis, delayed involution. J Cell Physiol. 2011;226:1340-52.

27. Desprez PY, Hara E, Bissell MJ, Campisi J. Suppression of mammary epithelial cell differentiation by the helix-loop-helix protein Id-1. Mol Cell Biol. 1995;15:3398-404.

28. Zeng YA, Nusse R. Wnt proteins are self-renewal factors for mammary stem cells and promote their long-term expansion in culture. Stem Cells. 2010;6:568-77

29. Guigon CJ, Kim DW, Willingham MC, Cheng S-Y. Mutation of thyroid hormone receptor-b in mice predisposes to the development of mammary tumors. Oncogene. 2011;30:3381-90.

30. Zinser G, Packman K, Welsh J. Vitamin D (3) receptor ablation alters mammary gland morphogenesis. Development. 2002;129:3067-76.

31. Dyer MA, Livesey FJ, Cepko CL, Oliver G. Prox1 function controls progenitor cell proliferation and horizontal cell genesis in the mammalian retina. Nat Genet. 2003;34:53-8.

32. Hope KJ, Cellot S, Ting SB, MacRae T, Mayotte N, Iscove NN, et al. An RNAi screen identifies Msi2 and Prox1 as having opposite roles in the regulation of hematopoietic stem cell activity. Stem Cells. 2010;7:101-13.

33. Sarrazin S, Mossadegh-Keller N, Fukao T, Aziz A, Mourcin F, Vanhille L, et al. MafB restricts M-CSF-dependent myeloid commitment divisionsof hematopoietic stem cells. Cell. 2009;138:300-13.

34. Onodera Y, Hashimoto S, Hashimoto A, Morishige M, Mazaki Y, Yamada A, et al. Expression of AMAP1, an ArfGAP, provides novel targets to inhibit breast cancer invasive activities. EMBO J. 2005;24:963-73.

35. Wigle JT, Harvey N, Detmar M, Lagutina I, Grosveld G, Gunn MD, et al. An essential role for Prox 1 in the induction of the lymphatic endothelial cell phenotype. EMBO J. 2002;21:1505-13.

36. Bouras T, Pal B, Vaillant F, Harburg G, Asselin-Labat M-L, Oakes SR, et al. Notch signaling regulates mammary stem cell function and luminal cell-fate commitment. Cell Stem Cell. 2008;3:429-41.
37. Guo W, Keckesova Z, Donaher JL, Shibue T, Tischler V, Reinhardt F, et al. Slug and Sox9 cooperatively determine the mammary stem cell state. Cell. 2012;148:1015-28.

38. Dai Z, Sheridan JM, Gearing LJ, Moore DL, Su S, Dickins RA, et al. edgeR: a versatile tool for the analysis of shRNA-seq and CRISPR-Cas9 genetic screens. F1000Res. 2014;3:95.

39. Elsir T, Smits A, Lindström MS, Nistér M. Transcription factor PROX1: its role in development and cancer. Cancer Metastasis Rev. 2012;31:793-805.

40. Petrova TV, Nykänen A, Norrmén C, Ivanov Kl, Andersson LC, Haglund C, et al. Transcription factor PROX1 induces colon cancer progression by promoting the transition from benign to highly dysplastic phenotype. Cancer Cell. 2008;13:407-19.

41. Dickins RA, Hemann MT, Zilfou JT, Simpson DR, Ibarra I, Hannon GJ, et al. Probing tumor phenotypes using stable and regulated synthetic microRNA precursors. Nat Genet. 2005;37:1289-95.

42. Paddison PJ, Cleary M, Silva JM, Chang K, Sheth N, Sachidanandam R, et al. Cloning of short hairpin RNAs for gene knockdown in mammalian cells. Nat Meth. 2004;1:163-7.

43. Merino D, Best SA, Asselin-Labat ML, Vaillant F, Pal B, Dickins RA, et al. Pro-apoptotic Bim suppresses breast tumor cell metastasis and is a target gene of SNAI2. Oncogene. 2014. doi: 10.1038/onc.2014.313.

44. Robinson MD, McCarthy DJ, Smyth GK. edgeR: a Bioconductor package for differential expression analysis of digital gene expression data. Bioinformatics. 2010;26:139-40.

45. Robinson MD, Smyth GK. Small-sample estimation of negative binomial dispersion, with applications to SAGE data. Biostatistics. 2008;9:321-32.

46. Liao Y, Smyth GK, Shi W. The Subread aligner: fast, accurate and scalable read mapping by seed-and-vote. Nucleic Acids Res. 2013;41:e108.

47. Liao Y, Smyth GK, Shi W. featureCounts: an efficient general purpose program for assigning sequence reads to genomic features. Bioinformatics. 2014;30:923-30.

48. Robinson MD, Oshlack A. A scaling normalization method for differential expression analysis of RNA-seq data. Genome Biol. 2010;11:R25.

49. Law CW, Chen Y, Shi W, Smyth GK. voom: Precision weights unlock linear model analysis tools for RNA-seq read counts. Genome Biol. 2014;15:R29.

50. Smyth GK: Linear models and empirical bayes methods for assessing differential expression in microarray experiments. Stat Appl Genet Mol Biol 2004, 3:Article3.

51. Ritchie ME, Phipson B, Wu D, Hu Y, Law CW, Shi W, et al. Limma powers differential expression analyses for RNA-sequencing and microarray studies. Nucleic Acids Research. 2015; doi: 10.1093/nar/gkv007.

52. Benjamini $Y$, Hochberg Y. Controlling the false discovery rate: a practical and powerful approach to multiple testing. J Royal Statistical Soc. 1995. Series B 57: 289-300.

\section{Submit your next manuscript to BioMed Central and take full advantage of:}

- Convenient online submission

- Thorough peer review

- No space constraints or color figure charges

- Immediate publication on acceptance

- Inclusion in PubMed, CAS, Scopus and Google Scholar

- Research which is freely available for redistribution 